\title{
Liberalizm wobec polaryzacji politycznych
}

\author{
Janusz A. MAJCHEREK*
}

\begin{abstract}
Liberalism and political polarization: The customary classification of the ideological doctrines in democratic systems, which expanded along a left-right axis, is nowadays obsolescent and has been deconstructed. At the same time, the close and strong connection between democracy and liberalism, on which the primary model of liberal democracy was established, has been broken in many places of the world. The emerging of illiberal democracies has made the liberal component the main criterion for the classification of contemporary political systems, instead of dividing them into democratic and nondemocratic systems as before. Numerous ideological options could also be classified as being contrary to the liberal one. Liberalism has thus become important in the typologies and analyses of contemporary political systems and ideological options as the opposite to those systems on many new axes.
\end{abstract}

\section{KEYWORDS}

illiberal democracy; ideological dichotomies; political pluralism

\footnotetext{
* Prof. dr hab., Instytut Filozofii i Socjologii, Uniwersytet Pedagogiczny w Krakowie. E-mail: janumaj@ists.pl.
} 


\section{LIBERALIZM WOBEC NIELIBERALNYCH DEMOKRACJI}

Silnym, a być może wręcz dominującym obecnie trendem politycznym w obrębie zachodniej cywilizacji (szeroko rozumianej, obejmującej Rosję i Turcję) jest osłabianie, redukowanie czy wręcz eliminowanie liberalnego komponentu demokracji liberalnej. Rezultatem i przejawem tego trendu jest kształtowanie i upowszechnianie się rozmaitych form demokracji nieliberalnych. Niezależnie od nazw nadawanych im przez samych ich inicjatorów, propagatorów i beneficjentów („suwerenna”, „ludowa” czy po prostu „prawdziwa”), politolodzy określają je jako „populistyczne”, „statystyczne”, „plebiscytarne” czy „formalne”, a nawet (nawiązując do analiz Jacoba Tolmana) „totalitarne”. Ich wspólną cechą jest zasadnicza i głęboka, a często wręcz radykalna zmiana proporcji między demokratycznym i liberalnym składnikiem systemu politycznego, polegająca na aprecjacji tego pierwszego i deprecjacji tego drugiego. Obserwator i badacz tego procesu Fareed Zakaria używa nawet określenia „nadmiar demokracji”, odzwierciedlającego narastającą asymetrię między plebiscytarną formą wyłaniania władzy (komponent demokratyczny) a ochroną praw jednostki, rządami prawa i rozdziałem Kościoła od państwa (komponent liberalny). „Nadmiar demokracji” oznacza nadużywanie demokratycznych procedur do legitymizowania nieliberalnych czy wręcz antyliberalnych działań politycznych (Zakaria, 2018: passim). Eksponowanie formalnie poprawnego sposobu zdobywania i legitymizowania władzy daje mu dominację nad łamiącym reguły sposobem jej sprawowania, będąc propagandowo nadużywanym: mandat uzyskiwany w demokratycznych procedurach wyborczych jest wykorzystywany do osłabiania wolności, swobód i praw obywatelskich, zwłaszcza przysługujących rozmaitym mniejszościom. W ten sposób aktualizuje się formułowana od czasów starożytnych przestroga przed wyradzaniem się demokracji w ochlokrację, ostrzeżenia Johna Stuarta Milla czy Alexisa de Tocqueville’a przed zagrożeniem dyktaturą większości, aż po napomnienia Karla Poppera czy wspomnianego Talmona przed niebezpieczeństwami użycia demokracji jako sposobu wyboru i kreowania dyktatorów. Potwierdza to taką wykładnię relacji między demokracją a liberalizmem, według której ta pierwsza chroni przed dyktaturą mniejszości, a ten drugi przed dyktaturą większości. Usunięcie któregokolwiek z tych dwóch komponentów oznacza likwidację bariery przed którąś z form dyktatury (Wróblewski, 2011: 157n.). To jeden z powodów, dla których Emmanuel Wallerstein uznał „nawiązanie rozsądnej relacji” między demokratyzacją a liberalizacją za wstępny warunek rozwiązania najważniejszych problemów i konfliktów społecznych XXI wieku (Wallerstein, 2004: 119).

Znana jest reguła, że dopiero strata uświadamia wartość utraconego („szlachetne zdrowie, / nikt się nie dowie, / jako smakujesz, /aż się zepsujesz”, „ile cię trzeba cenić, ten tylko się dowie, / kto cię stracił"). Zgodnie z nią to właśnie osłabianie, redukowanie czy wręcz eliminowanie liberalnego komponentu 
demokracji liberalnej odkrywa i ukazuje jego znaczenie. Paradoksalnie zatem, gdy słabnie realny wpływ liberalnego składnika demokracji na praktykę jej funkcjonowania, rośnie jego ranga w świadomości obywateli oraz teoretyków i analityków. Dwadzieścia kilka lat temu Jerzy Szacki pisał, że „liberalizm wtopił się, by tak rzec, w szerokie tło liberalnej demokracji, tracąc tym samym wiele ze swej, kiedyś względnie wyrazistej, tożsamości” (Szacki, 1994: 28). Obecnie mamy do czynienia z procesami i zjawiskami przeciwnymi: osłabianie czy wręcz eliminowanie liberalnego komponentu demokracji liberalnej uwypukla znaczenie i uwyraźnia tożsamość liberalizmu. Sytuuje się on wręcz - w różnych wszakże odmianach - jako jeden z biegunów newralgicznych polaryzacji politycznych, w których wyrażają się główne konflikty i antagonizmy społeczne we współczesnych państwach demokratycznych. Można je bowiem opisać jako konfrontację liberalizmu z różnymi odmianami ideologii czy doktryn antyliberalnych lub przynajmniej nieliberalnych. W ten sposób da się zinterpretować nowe formy polaryzacji stanowisk politycznych, w miejsce dość powszechnie kwestionowanego i porzucanego, tradycyjnego antagonizmu lewica-prawica. W tymże liberalizm sytuował się w pozycji pośredniej lub pobocznej. W pierwszym przypadku był zgniatany z dwóch stron przez oba rywalizujące i napierające na siebie bloki polityczne (tym bardziej, że przez każdy z nich traktowany jako należący do przeciwnego) ${ }^{1}$. W tym drugim był marginalizowany jako nieistotny dla wyniku głównej rywalizacji (bo miałki, jałowy, niewyraźny, nieokreślony, chwiejny ideowo). Uplasowanie go jako biegunowego, czyli jednego z głównych protagonistów rywalizacji politycznej, wydatnie podnosi jego rangę, ale też wikła go w wiele konfliktów i napięć ideowych.

1. Liberalizm-socjalizm. Ta dychotomia ma już w znacznym stopniu charakter historyczny, była bowiem elementem konfrontacji między obozem władzy PRL i demokratyczną wobec niego opozycją oraz następstwem upadku realnego socjalizmu, zwłaszcza w Polsce, gdzie został on - przede wszystkim w gospodarce - wyparty przez liberalne reformy ${ }^{2}$. Jak zauważał Szacki, „negacja komunizmu i szukanie jakiejś kontrapozycji były naturalnym źródłem sympatii liberalnych, liberalizm bowiem nadawał się wręcz idealnie do roli takiej kontrapozycji” (Szacki, 1994: 91). Kontrapozycję tę uwypukla i wzmacnia bezpośredni oraz bliski — przynajmniej historycznie — związek liberalizmu z kapitalizmem,

${ }^{1}$ Tara Ella stwierdza, że w USA wielu konserwatystów uważa liberalizm po prostu za odmianę socjalizmu, a w Australii Partia Liberalna jest usytuowana na centroprawicy, mając silny odcień konserwatywny (Ella, 2017: 6, 29). W Polsce konserwatyści często utożsamiają liberałów z lewicą i zwalczają jako jej część, gdy socjaliści zaliczają ich do potępianej przez siebie prawicy (Sosnowski, 2011: 59-60). To uwypukla nieadekwatność klasyfikacji dokonywanych według osi lewica-prawica.

${ }^{2}$ Choć w szerszym planie historycznym antagonizm liberalizm-socjalizm jest dawny, bo sięga połowy XIX wieku, i miał nader burzliwy przebieg (Bobbio, 1998: 54n.). 
przeciwstawnym socjalizmowi na płaszczyźnie ekonomicznej (Szacki, 1994: 62-63). Szacki zwracał uwagę na szczególną pozycję liberalizmu w postkomunistycznej Europie, a zwłaszcza Polsce, gdzie „musiał się pojawić jako niezbędny układ odniesienia każdej poważnej dyskusji o dalszej drodze krajów zrujnowanych przez eksperyment komunistyczny" (Szacki, 1994: 16). Ponieważ systemowa transformacja była rozumiana jako liberalizacja (nie tylko ekonomiczna), zatem jej przeciwnicy i krytycy identyfikowali się jako antyliberałowie, co jeszcze bardziej uwypuklało dychotomiczny podział, którego liberalizm był biegunem.

Nawet mnożące się ataki na liberałów świadczą poniekąd o jego sukcesie [...]. Wszystko wskazuje bowiem na to, że po totalnej kompromitacji zetatyzowanego do absurdu, i jeśli nawet nie totalitarnego, to wyraźnie autorytarnego realnego socjalizmu pojawienie się liberalizmu (i to w wersji, by tak rzec, mocnej) jest psychologiczną i społeczną koniecznością (Szacki, 1994: 10).

W tym kontekście przywoływał Szacki konstatację jednego ze wschodnioeuropejskich analityków, że urok i siła liberalizmu ujawnia się szczególnie tam, gdzie konfrontowat się on z socjalizmem.

Dlatego liberalizm jest nadal często postrzegany jako antidotum wobec zagrożenia recydywą socjalizmu w jego mniej lub bardziej autorytarnej postaci (często frazeologicznie zakamuflowanej w związku z historyczną kompromitacją jego wersji sowieckiej i PRL-owskiej). Głównym punktem spornym jest stosunek do własności prywatnej, od czasów Johna Locke’a stanowiący jeden z filarów liberalnej koncepcji człowieka i społeczeństwa, zakładającej, że „wolność osobista implikuje prywatną własność silnie chronioną przepisami prawa” i że „w społeczeństwie obywatelskim konieczne jest szerokie upowszechnienie własności prywatnej” (Gray, 1994: 26).

A przy tym liberalizm pozostaje w trwałym konflikcie z socjalizmem o prymat w procesach modernizacyjnych (o czym niżej).

2. Liberalizm-populizm. To bardziej aktualna dychotomia, wywodząca się ze wspomnianego przeciwstawienia demokracji liberalnej i demokracji populistycznej. Ta pierwsza odwołuje się do partycypacji obywatelskiej jednostek zachowujących swoją autonomię i prawa bez względu na wynik zaangażowania w polityczną konfrontację; ta druga demagogicznie powołuje się na substancjalnie rozumiany lud (naród, suwerena) i jego zbiorową wolę, mającą prymat nad prawami owych jednostek, lub je ignoruje w imię demokratycznego werdyktu. „Populista zawsze brzmi jakoś «roussoistycznie»” (Müller, 2017: 48). Skoro - jak stwierdził Szacki - system uprawnień jednostki jest „archimedesowym punktem” liberalizmu, od którego się zaczyna i na którym się koncentruje (Szacki, 1994: 40), zatem jego antagonizm z populizmem staje się nieuchronny. Jak wskazuje Norberto Bobbio, proceduralne i formalne rozumienie 
demokracji (jako systemu wyłaniania władzy) umożliwia harmonijne jej zespolenie z liberalizmem (a więc powstanie i funkcjonowanie demokracji liberalnej). Natomiast substancjalne, esencjalne, a zwłaszcza moralne rozumienie demokracji (władzy ludu jako samoistnego podmiotu o moralnym statusie) prowadzi do zawikłania tych relacji i nadania im często antagonistycznego charakteru (Bobbio, 1998: 24n.). Demagogicznie forsowany moralny prymat substancjalnie i organizmalnie pojmowanego ludu to charakterystyczna cecha populizmu. Jak stwierdza Immanuel Wallerstein, „demokracja powinna być liberalna, aby nie stała się populistyczna" (Wallerstein, 2004: 128). Albo liberalna, albo populistyczna; albo liberalizm, albo populizm.

W podobny sposób ujął to William $\mathrm{H}$. Riker w książce Liberalism against populism, opublikowanej w 1982 roku. W ujęciu tym ilościowa kategoria większości nie przekłada się na jakościową (normatywną) kategorię słuszności czy sprawiedliwości, dlatego (aksjo-)normatywne podstawy demokracji muszą mieć umocowanie $\mathrm{w}$ instytucjach, zwłaszcza chroniących indywidualną wolność obywateli, a tę najlepiej zabezpiecza (bo najwyżej ceni) liberalizm. Dlatego demokracja musi być liberalna, a więc antypopulistyczna. Do tego wywodu nawiązuje Maija Setälä, dokonując formalnego przeciwstawienia liberalizmu i populizmu w kontekście praktyk referendalnych (a więc odwołujących się bezpośrednio do woli większości) oraz normatywno-instytucjonalnych podstaw liberalnej demokracji (Setälä, 1999: 49).

Wspomniany wcześniej „nadmiar demokracji” w rozumieniu Zakarii wyraża się poprzez odwołanie do populizmu jako sposobu uzyskania legitymizacji działań antyliberalnych. Müller potwierdza: demokracja populistyczna to demokracja zdegenerowana (Müller, 2017: 21)

Przeciwstawienie liberalizmu i populizmu w interpretacji Szymona Wróbla jest wyrazem lękowej reakcji na ten pierwszy, przejętej i wykorzystanej przez ten drugi. Populizm to lękowe przeciwstawienie się liberalizmowi (Wróbel, 2015: 184). Można dodać, że ów lęk często jest przez populistów kreowany i podsycany, a nie tylko wykorzystywany. Wyrazistość konfrontacji liberalizmu z populizmem wynika stąd, że oba sytuują się poza polaryzacją lewica-prawica (populizm może być zarówno lewicowy, jak prawicowy).

3. Liberalizm-autorytaryzm. Dychotomia ta jest poniekąd konsekwencją czy przynajmniej paralelą poprzedniej, bowiem demokracja populistyczna wynosi na ogół do władzy polityków autorytarnych (populistów), korzystających z formalnych, statystycznych czy plebiscytarnych form jej uzyskiwania i legitymizowania, a następnie umacniania i poszerzania, kosztem wolności, swobód i praw obywatelskich (tutaj archetypicznym, choć skrajnym, lecz przez to wyrazistym

${ }^{3}$ „Roszczenie [populistów] do wyłącznej reprezentacji nie ma charakteru empirycznego, lecz wyraźnie moralny” (Müller, 2017: 17). 
przykładem jest demokratyczna droga przechwycenia władzy przez Adolfa Hitlera). Müller stwierdza, że populizm jest zarówno antyliberalny, jak i - w rezultacie - antydemokratyczny, bowiem wykorzystując demokratyczne formy legitymizowania władzy prowadzi do degeneracji demokracji, a w rezultacie do autorytaryzmu. Przychyla się do takiej konstatacji Zakaria: „pozbawiony liberalnych obwarowań i niesprawny system demokratyczny może zdyskredytować samą ideę demokracji” (Zakaria, 2018: 292). Tak działo się wielokrotnie w historii, poczynając od wyrodzenia się demokracji greckiej w tyranię, dzieje się także w dzisiejszym świecie, gdzie wiele demokracji — zwłaszcza pozaeuropejskich — przekształciło się w dyktatury rozmaitych autokratów. Liberalizm ma więc swoje miejsce i rolę do odegrania w przeszłości, teraźniejszości i przyszłości, dopóki występują i będą występować tendencje autorytarne — jeśli bowiem jest zorientowany antyautorytarnie, to każdy krok czyniony gdziekolwiek $\mathrm{w}$ stronę autorytaryzmu generuje potrzebę liberalnej mobilizacji i kontrakcji.

A pokusa i groźba autorytaryzmu jest obecna zarówno na lewo, jak i na prawo od liberalizmu. „Demokratyczny socjalizm” w praktyce politycznej przekształca się często w „demokrację socjalistyczną”, będącą jedną z form autorytaryzmu. Podobnie „narodowa demokracja” zbacza ku nacjonalistycznej dyktaturze. Liberalna demokracja jest skonfrontowana z obiema tymi pokusami i groźbami („demokracji socjalistycznej” i „demokracji narodowej”), a liberalizm z wszelkim autorytaryzmem. Jean Blondel uważa opozycję liberalizmu i autorytaryzmu za kluczową dla typologii i charakterystyki systemów politycznych, które da się usystematyzować według osi poprowadzonej między tymi dwoma biegunami. „Systemy polityczne mogą być albo bardziej lub mniej liberalne, albo bardziej lub mniej autorytarne" (Blondel, 2013: 30, 34 [wykres]) $)^{4}$. Albo liberalizm, albo autorytaryzm.

4. Liberalizm-konserwatyzm. To wyraz przeciwstawienia modernizacji i tradycji jako dwóch osiowych stanowisk wobec globalizacji oraz przemian społecznych, ekonomicznych i technologicznych. Niegdyś była to oś wytyczana według utartego przeciwstawienia lewica-prawica, gdzie lewica była zorientowana modernizacyjnie, a prawica tradycjonalistycznie (konserwatywnie). Jak już wspomniano, ta postać polaryzacji rozmywa się, nie bez związku z retrospektywnym nastawieniem części lewicy, nawołującej do restytucji stosunków ekonomicznych, społecznych i politycznych z lat sześćdziesiątych i siedemdziesiątych XX wieku czy przejęciem przez nią haseł i programów proekologicznych, a więc propagujących zachowanie (konserwowanie) dziedzictwa przyrodniczego, kosztem rezygnacji z nowoczesnych technologii, wzrostu efektywności i rozwoju gospodarczego, gdy konserwatywna prawica przyswoiła hasła i programy bezwzględnego przyspieszania rozwoju gospodarczego (turbokapitalizm), nawet za cenę naruszenia zasobów i dóbr natury.

\footnotetext{
${ }^{4}$ Cytaty z prac obcojęzycznych, jeśli nie zaznaczono inaczej, w przekładzie autora.
} 
W specyficzny sposób wyraziła się ta tendencja i po części wyraża nadal w Stanach Zjednoczonych (gdzie jednak także ustępuje przed polaryzacją na osi liberalizm-populizm). Gdy tamtejsi konserwatyści przejęli liberalną doktrynę ekonomiczną (zreinterpretowaną jako neoliberalizm), główny antagonizm polityczny przybrał formę konfliktu dwóch odmian liberalizmu: socjalliberalizmu Partii Demokratycznej i neoliberalizmu republikanów (jak to ujął Paweł Kłoczowski, „wszystkie liczące się orientacje polityczne mają tam charakter liberalny, przy czym prawica podkreśla prawa ekonomicznego leseferyzmu, zaś lewica wysuwa na plan pierwszy roszczenia socjalne i obyczajowe" [Kłoczowski, 1999: 260] $)^{5}$. Podobne procesy zaszły w Wielkiej Brytanii oraz w mniej wyrazistej postaci w Europie kontynentalnej (gdy lewica stawała się bardziej liberalna ekonomicznie, a prawica obyczajowo; przedstawiciele Nowej Lewicy wprowadzali zmiany liberalizujące gospodarkę, jak w Niemczech, a torysi uchwalali prawo wprowadzające małżeństwa homoseksualne jako wzmacniające instytucję rodziny). Jak to ujął John Gray, „podobnie jak jedyną do przyjęcia postacią konserwatyzmu okazał się konserwatyzm liberalny, tak socjalizm osiągał pewne sukcesy, jeżeli wchłonął podstawowe elementy cywilizacji liberalnej" (Gray, 1994: 105). To jeszcze bardziej podniosło rangę liberalizmu jako newralgicznej doktryny politycznej i ekonomicznej, a także formacji kulturowej (czy wręcz cywilizacyjnej, jak w ujęciu Graya). Liberalizacja postępowała we wszystkich obszarach, wywołując oczywiście reakcję (kontrakcję) — często konserwatywną (socjalistyczna jest obecnie znacznie słabsza). Wyraża się to w przeciwstawieniu w takich obszarach życia społecznego jak rodzina, seksualizm, patriotyzm (stosunek do związków i małżeństw nieheteronormatywnych, aborcji, antykoncepcji czy zapłodnienia pozaustrojowego, form realizowania obowiązków obywatelskich) (Smith, 2014). To są bodaj główne obecnie tematy debat publicznych o szczególnie polaryzującym charakterze, niekiedy prowadzącym do przekształcania się we wzmiankowane „wojny kulturowe”.

${ }^{5}$ Przeciwstawienie konkretnych cech liberalizmu i konserwatyzmu w ich amerykańskim rozumieniu i wydaniu przedstawia tabelaryczne ujęcie Steve'a Olsena w jego książce Why you may be a liberal (and why that's okay) na s. 16-17 (b.m. i d.w.). Jako zbyt partykularnie amerykańskie nie będzie tu jednak przywołane, podobnie jak wywody George'a Lakoffa, wyjaśniającego w książce Moral politics. How liberals and conservatives think (Chicago 2016) różnice między liberalnym i konserwatywnym poglądem na świat jako wynikające $z$ wrodzonych i nieuświadamianych predyspozycji mentalnych, odzwierciedlanych w metaforach służących konceptualizacji świata w określony sposób. W istocie odwołują się one do podziałów światopoglądowych występujących w społeczeństwie amerykańskim, stąd nie tylko ich ograniczona wartość heurystyczna, ale także wątpliwości co do ich faktycznego zakorzenienia we wrodzonych strukturach umysłu oraz uniwersalności jego radialnej teorii znaczenia, na których je opiera. Ten sam antagonizm jest — za Jamesem Hunterem — opisywany jako wojna kulturowa, co ma znacznie szersze odzwierciedlenie w społecznych i ideologicznych podziałach poza USA oraz zastosowanie do ich analizy. 
5. Liberalizm-komunitaryzm. To z kolei odzwierciedlenie najważniejszego sporu w filozofii politycznej ostatnich kilku dekad, wywołanego ukazaniem się głośnej i znaczącej książki Johna Rawlsa Teoria sprawiedliwości. Warto przy tej okazji zaznaczyć, że później dokonał on dodatkowej nobilitacji liberalizmu w książce Liberalizm polityczny, odróżniając go jako formę organizacji życia politycznego w (liberalnej) demokracji od jednej z formacji światopoglądowych biorących $\mathrm{w}$ życiu tym (i demokratycznej rywalizacji) udział. Liberalizm został tym samym usytuowany na politycznym metapoziomie. Uplasowany na obu tych płaszczyznach, zyskał jeszcze wyższą rangę. Cytowane już stwierdzenie Szackiego, że „archimedesowym punktem” liberalizmu jest system uprawnień jednostki (w lapidarnym ujęciu Bobbio „bez indywidualizmu nie ma liberalizmu” [Bobbio, 1998: 10]), wyróżnia i przeciwstawia go innym „szkołom” filozofii społecznej, których punktem wyjścia są potrzeby wspólnoty (Szacki, 1994: 40-41). Biegunowe usytuowanie liberalizmu na takiej osi polaryzacyjnej jest więc nieakcydentalne i nieusuwalne. Zwłaszcza na obszarze Europy Wschodniej, gdzie - jak zauważał Szacki - szczególnie szerzyły się ideologie kolektywistyczne (Szacki, 1994: 136). Współcześni antyliberalni komunitaryści to także często propagatorzy i obrońcy zamkniętych, ekskluzywistycznych, silnie wewnętrznie zespolonych wspólnot, zwłaszcza narodowych, opartych na więziach wytwarzanych i podtrzymywanych przy użyciu zamkniętych kodów kulturowych. Dlatego ta forma polaryzacji przybiera często postać innej: społeczeństwo otwarte - społeczeństwo zamknięte, odtwarzając dychotomię i antagonizm opisane przez Poppera. Narastanie tendencji kolektywistycznych i ekskluzywistycznych wytwarza oczywiste zapotrzebowanie na przeciwstawne tendencje indywidualistyczne i inkluzywistyczne reprezentowane przez liberalne podejście do zagadnień społecznych.

Ale u podstaw tego liberalno-komunitarystycznego antagonizmu leżą na co zwracało uwagę wielu analityków i komentatorów - fundamentalne różnice filozoficzne dotyczące kwestii podmiotowości, jaźni, tożsamości czy racjonalności.

Liberał-filozof nie mógłby zaakceptować wizji suwerennej jednostki, z której jednocześnie wynikałoby, że człowiek musi podlegać określonej tradycji, dzielić z innymi pewne dobra i uczestniczyć w świecie wspólnych wartości. Z kolei komunitarysta-filozof nie zgodzitby się na rozumienie odpowiedzialności jako drogi do separacji jaźni w stosunku do wszelkich koncepcji i ideałów dobra oraz zastąpienia ich racjonalnością (Turowski, 2011: 64).

A przy tym wielu liberałów (Kelly, 2007: 21) eksponuje etyczny sens tego przeciwstawienia (podmiotem moralnym oraz przedmiotem moralnej troski i szacunku, bez względu na przynależność i identyfikację grupową, jest jednostka, a nie zbiorowość) bez konieczności przesądzania kwestii z zakresu ontologii: 
tego rodzaju pogląd nie zakłada określonej ontologii społecznej ani określonego sposobu kształtowania czy nadawania jednostkowej tożsamości w ramach grupy. Zakłada jedynie, że społeczne lub psychospołeczne uwarunkowania tożsamości nie decydują o etycznym ani o normatywnym znaczeniu (Kelly, 2007: 21).

Jak stwierdza przywoływana już liberalna feministka Tara Ella, liberalizm jest ideologią, do istoty której należy przekonanie, że wszyscy ludzie są równi pod względem moralnym, czyli mają równe prawo odgrywania moralnych ról, a doktrynalna reszta liberalizmu wynika $\mathrm{z}$ tego założenia jako podstawowego (Ella, 2017: 12, 18).

Tymczasem komunitaryzm eksponuje grupowe ustalenia i ustanowienia, także w kwestiach moralnych, w tym moralnego statusu osób ludzkich. Liberalizm zaś umożliwia nie tylko uwolnienie od indywidualnej, ale także wewnątrzgrupowej i międzygrupowej opresji i tyranii (o czym sugestywnie pisał Mill, przeciwstawiając się tyranii większości i despotyzmowi opinii publicznej). „Oddzielając tożsamość polityczną (obywatelstwo) od tożsamości grupowej, a w konsekwencji uznając wszystkich obywateli za podmioty o równej wartości i statusie, liberalizm rozwiązuje konflikt tożsamości i przynależności” (Kelly, 2007: 191). A Ella dodaje, że przyjmując moralną równość ludzi, liberalizm jako jedyny chroni ich przed opresją ze strony zbiorowości (Ella, 2017: 18). Ukute przez konserwatystów pojęcie „moralnej większości” wydaje się bodaj najbardziej wyrazistym przeciwieństwem liberalnego poglądu o moralnej równości ludzi (obywateli).

6. Liberalizm-solidaryzm. Polaryzacja ta jest szczególnie charakterystyczna dla sytuacji w Polsce, gdzie wyrażona została dokonanym niegdyś przeciwstawieniem „Polski solidarnej” „Polsce liberalnej”. Wiąże się z rolą i statusem Solidarności jako ruchu obywatelskiego i formacji ideowo-politycznej.

Solidaryzm to doktryna społeczno-polityczna o pochodzeniu francuskim, tam wytworzona, ale zaadaptowana (zwłaszcza w i po encyklice Rerum novarum Leona XIII) przez Kościół katolicki, włączona do jego nauki społecznej i obecnie z nim przede wszystkim utożsamiana. Nic więc dziwnego, że przywoływana jest przez środowiska polityczne z Kościołem i katolicyzmem powiązane i kooperujące. Ich stosunkowo duża liczebność i siła wpływów czyni przywoływany i promowany przez nie solidaryzm stanowiskiem znaczaccym. W stosunku do liberalizmu oznacza ono inne pojmowanie najistotniejszych kompleksów wartości, o które chodzi, wartości narodowych, a nawet wartości religijnych. A także inne definiowanie państwa i jego demokratycznych zasad (Krzemiński, 2015: 157).

Newralgiczne dla przeciwstawienia solidaryzmu i liberalizmu są różnice w ujmowaniu relacji między prawami (uprawnieniami) jednostki a jej obowiązkami (zobowiązaniami) wobec zbiorowości. O ile solidaryzm podkreśla prymat tych drugich (wypełnianie obowiązków jest warunkiem korzystania z praw), liberalizm przeciwnie (trzeba mieć swobodę korzystania z praw, aby móc wypełniać 
obowiązki). Zarówno związany z katolicyzmem Michael Novak, jak i uchodzący za doktrynalnego liberała Ludwig von Mises, uznali solidaryzm za bliski socjalizmowi. Novak wylicza: oba dezawuują twórczą inwencję menadżerów, inwestorów i handlowców; oba deprecjonują kreatywność jednostek; oba przyjmują, że jednostka jest nieodłączną częścią wspólnoty. Solidaryzm ogranicza wprawdzie władzę państwową, ale poprzez własną doktrynę i wymóg dostosowania władzy do niej, a nie poprzez instytucjonalny podziat i kontrolę (checks and balances), jak postuluje liberalizm. Ale solidaryzm i liberalizm mają też wspólne założenie o dobroczynnych skutkach prywatnej własności (Novak, 2000: passim). Według Misesa liberalizm i solidaryzm faktycznie mają pewien wspólny punkt wyjścia uznanie, że prywatna własność służy ogółowi, a nie tylko właścicielowi. Ich drogi potem rozchodzą się jednak - solidaryzm odrzuca koncepcję samoczynnego ładu wytwarzanego pomiędzy indywidualnymi podmiotami swobodnych umów oraz transakcji zawieranych na wolnym rynku i przy gwarantowanej swobodzie. Solidaryzm postuluje natomiast wprowadzenie dodatkowego, nadrzędnego czynnika harmonizującego: w wersji religijnej transcendentnego, a więc Boga i w rezultacie (jakiegoś) Kościoła, a w wersji świeckiej — państwowego. „Solidaryzm poddaje własność «Najwyższemu Prawu»; innymi słowy, znosi ją” (Mises, 2009: 265). To prowadzi do etatyzmu, który jest dodatkowym przeciwieństwem liberalizmu i wzmocnieniem tej osi polaryzacyjnej.

\section{PODSUMOWANIE: LIBERALNY PLURALIZM WOBEC DOKTRYNALNEGO MONIZMU}

Biegunowe usytuowanie liberalizmu na licznych osiach polaryzujących konfrontację ideową i rywalizację polityczną dodaje mu znaczenia, ale także wikła go $\mathrm{w}$ wiele konfliktów. Wynika to z jego wielorakości i wieloodmienności. Zaznaczyło się to wyraźnie w toku polskiej transformacji, uważanej za liberalną i z liberalizmem kojarzonej, co nastawiło antyliberalnie wszystkich jej krytyków i oponentów. Ale tym bardziej uwypukliło to biegunowe usytuowanie liberalizmu na osi polaryzującej stanowiska doktrynalne i rywalizację polityczną w systemie postkomunistycznym. Przezwyciężenie podziału postkomunistycznego nie zmieniło tej sytuacji zasadniczo, gdyż liberalizm pozostawał głównym oponentem i antagonistą w nowych podziałach i polaryzacjach. Wynika to stąd, że „liberałowie są inni nie tylko dlatego, że są, dajmy na to, mniej dogmatyczni i bardziej tolerancyjni od konserwatystów, nacjonalistów czy socjalistów" (Szacki, 1994: 44). Są od nich istotnie, esencjalnie, a nie akcydentalnie czy kwantytatywnie, inni ${ }^{6}$. A to oznacza, że są różni od nich wszystkich, zatem przeciwstawni im i tworzący układ odniesienia (przeciwstawienia) dla nich.

\footnotetext{
${ }^{6}$ Nietrafność, by nie powiedzieć niedorzeczność, ujmowania kluczowej dla liberalizmu
} kwestii wolności indywidualnej w kategoriach ilościowych i stopniowalnych pokazuje Leszek 
Ale to jednocześnie prowadzi do zróżnicowania wewnątrz liberalizmu. Jeśli tożsamość opiera się na różnicy, to jest ona odmienna w zależności od układu odniesienia (odróżnienia). Antysocjalistyczne usytuowanie liberalizmu nadaje mu innych cech niż antykonserwatywne, a przeciwstawienie komunitaryzmowi innych niż autorytaryzmowi. Dlatego można za Andrzejem Szahajem stwierdzić, że „nie ma liberalizmu w ogóle, jest wiele liberalizmów” (Szahaj, 2011: 35). Purystycznie nastawieni teoretycy poczytują tę wielowymiarowość, wieloaspektowość i wielorakość za wadę, gdyż utrudnia im definicyjne precyzacje (niektórzy kwestionują więc stosowanie określenia „liberalizm” dla niektórych spośród tych stanowisk) ${ }^{7}$. Innym teoretykom daje to asumpt do mnożenia dystynkcji i kontrapozycji wewnątrzliberalnych (liberalizm strachu - liberalizm odwagi, liberalizm racjonalistyczny - liberalizm sceptyczny, liberalizm doktrynerski - liberalizm etyczny, liberalizm utopijny — liberalizm doktrynerski itd.), niekiedy skwapliwie wykorzystywanych przez krytyków do imputowania wewnętrznych sprzeczności i w rezultacie dezawuowania liberalizmu jako niespójnego i niekonsekwentnego stanowiska intelektualnego. Ale jednocześnie stwarza to możliwość refutacji wielu zarzutów jako stosujących się do jednej tylko lub niektórych jego odmian, a nieadekwatnych wobec innych. Z praktycznego (politycznego, a nie politologicznego czy filozoficznego) punktu widzenia ta wielowymiarowość czy wielorakość jest niewygodna, bo sytuuje liberalizm wobec wielu antagonistów. Ale jednocześnie świadczy o randze i znaczeniu, bo plasuje go biegunowo na licznych osiach polaryzacyjnych, a więc pokazuje jego znaczenie dla ich konstruowania i organizowania (a także analizowania) przy ich pomocy życia społeczno-politycznego.

A ponadto ta wielorakość odzwierciedla znamienny dla liberalizmu aprobatywny stosunek do różnic, antagonizmów i konfliktów, przeciwstawny dążeniu

Kołakowski w stwierdzeniu, że wówczas różnica między liberalizmem a autorytaryzmem czy nawet totalitaryzmem sprowadza się do tego, że w tym drugim wolności jest mniej (Kołakowski, 1996: 138-139). Do tego prowadzą też bodaj próby konkretyzacji wolności w formie partykularnych swobód, praw czy „ograniczeń zewnętrznych”: można wówczas różnice między systemami liberalnymi i nieliberalnymi sprowadzać do ilości i wielkości zakresu owych swobód, praw itp. (nawet cenzura pozostawia pewien zakres wolności słowa, a do tego autorytaryści gwarantują - czy obiecują - „prawo do pracy”, „prawo do mieszkania”, „prawo do wypoczynku” itp.). „Policzenie wolności jest niemożliwe” — stwierdza równie lapidarnie co dosadnie John Gray (Gray, 2001: 152).

${ }^{7}$ Skądinąd nie mniejszych problemów definicyjnych nastręczają pojęcia konserwatyzmu czy socjalizmu, dlatego i w ich przypadkach zdarza się nierzadko kwestionowanie użycia tych pojęć wobec konkretnych doktryn, stanowisk czy ruchów politycznych, na przykład dość powszechne wśród lewicowo nastawionych teoretyków podważanie zasadności stosowania określenia „socjalizm” wobec systemu panującego w PRL albo spór o to, czy Solidarność była ruchem antysocjalistycznym czy właśnie socjalistycznym. Z kolei John Gray uznał, że we współczesnym świecie także „konserwatyzm przestał być spójną filozofią społeczną” z powodu wielości tradycji będących do dyspozycji: „,etyczny pluralizm społeczeństw późnonowoczesnych uczynił konserwatyzm niekoherentnym" (Gray, 2001: 89, 91). 
do jedności, harmonii i spójności, charakterystycznemu dla rozmaitych autorytaryzmów (despotyzmów) i teorii organicznych (holistycznych), opiewających podporządkowanie nadrzędnej strukturze czy wspólnocie ${ }^{8}$. Walkę z „przymusową przynależnością do «organicznych», mniej lub bardziej zamkniętych wspólnot, wyznaczających swoim członkom ściśle określone role społeczne, plany życiowe i rytuały obyczajowe" wymienia Andrzej Walicki jako jeden z głównych punktów liberalnej tradycji (Walicki, 2015: 202). „Akceptacja odmienności to główna cecha teorii i praktyki współczesnego liberalizmu" (Turowski, 2011: 97). Według Adama Chmielewskiego istotą liberalizmu jest metoda „udomawiania antynomiczności życia społecznego", wynikająca z przekonania o nieusuwalności owych antynomii. „Sprzeciwiając się monizmowi filozoficznemu, liberalizm jest więc filozofią różnorodności, która wynika ze zrozumienia różnicy jako konstytutywnego elementu życia społecznego" (Chmielewski, 1999: 244)9. Afirmuje on zróżnicowanie i skonfliktowanie odmiennych opcji jako nie tylko zabezpieczające przed wymuszoną lub narzuconą jednością czy zgodą, lecz także umożliwiajace rozwój, dokonywany dzięki rywalizacji i konkurencji rozmaitych pomystów (Bobbio, 1998: 18-20). Przyznaje to Wallerstein, przedstawiając liberalizm jako afirmatywnie nastawiony wobec ruchu i zmian, a więc także postępu (Wallerstein, 2004: 121). Szymon Wróbel za szczególny rys liberalizmu uważa autokrytycyzm, gotowość do rewizji, ironię i autosceptycyzm.

Tylko postawa liberalna namawia do stałego rewidowania swych przekonań i nie pozwala nam traktować zbioru swych poglądów jako zbioru raz na zawsze zamkniętego. Każdy inny światopogląd namawia nas do identyfikacji z jakimś ostatecznym zbiorem prawd, natomiast liberalizm w zamierzeniu wyzwala w nas jedynie odwagę i gotowość do czynienia użytku ze swego rozumu, co nie oznacza niczego innego, jak tylko gotowość do stałej rewizji swych pozycji intelektualnych i politycznych (Wróbel, 2015: 186).

A przy tym, jak wskazuje Gray, „liberalizm pozostaje koncepcją integralną” i wyraźnie odrębną od innych (to podkreśla także Ella), „trwałą, choć zmienną koncepcją człowieka i społeczeństwa" (Gray, 1994: 9). Jako taka stanowi nie tylko permanentne wyzwanie intelektualne, ale także układ odniesienia dla

${ }^{8}$ Nieprzypadkowo organicyzm jest wpisany w deklarację ideową ONR (pkt 5).

${ }^{9} \mathrm{Na}$ nieporozumieniu opiera się zarzut Ryszarda Legutki, że deklarując werbalnie afirmację pluralizmu, liberalizm redukuje go do dualizmu: „wielu liberałów (zwłaszcza w ostatnich dziesięcioleciach), głosząc nieustannie pochwały pluralizmu, posługuje się tak naprawdę nie pluralistyczną, lecz dualistyczną wizją rzeczywistości: z jednej strony widzą pluralizm, z drugiej monizm” (Legutko, 2011: 25). Afirmując pluralizm, liberałowie przeciwstawiają go monizmowi rozumianemu jako przymusowa jedność, stąd dychotomie liberalizm-autorytaryzm, ale również liberalizm-solidaryzm, omówione wcześniej, a także dokonane przez Chmielewskiego odróżnienie dwóch koncepcji jedności - w skrócie: narzuconej przez jedną opcję oraz wynegocjowanej pomiędzy różnymi opcjami (Chmielewski, 2006). Müller uważa dążenie do jedności na własnych warunkach za typowy rys populizmu i autorytaryzmu (Müller, 2017: 8-9); „populiści są zawsze przeciwnikami pluralizmu” (Müller, 2017: 17). 
debat toczonych na gruncie filozofii politycznej i społecznej. Ma więc wobec nich walor porządkujący, który warto uwypuklić i uwzględniać w analizach politycznych.

\section{BIBLIOGRAFIA}

Blondel, J. (2013). Comparative government. An introduction. London-New York: Routledge.

Bobbio, N. (1998). Liberalizm i demokracja. (Przeł. P. Bravo). Warszawa-Kraków: Fundacja Batorego / Znak.

Chmielewski, A. (1999). Filozoficzna idea liberalizmu (s. 235-256). W: J. Miklaszewska (Red.). Liberalizm u schytku XX wieku. Kraków: Meritum.

Chmielewski, A. (2006). Dwie koncepcje jedności. Interwencje filozoficzno-polityczne. BydgoszczWrocław: Oficyna Wydawnicza Branta.

Ella, T. (2017). Liberal revival now. A moral and practical case for a 21st century back-to-basics liberalism. B.m.w.

Gray, J. (1994). Liberalizm. (Przeł. R. Dziubecka). Kraków: Znak.

Gray, J. (2001). Dwie twarze liberalizmu. (Przeł. P. Rymarczyk). Warszawa: Aletheia.

Kelly, P. (2007). Liberalizm. (Przeł. S. Królak). Warszawa: Sic!

Kłoczowski, P. (1999). Czy liberalizm wystarczy? (s. 257-264). W: J. Miklaszewska (Red.). Liberalizm u schytku XX wieku. Kraków: Meritum.

Kołakowski, L. (1996). Gdzie jest miejsce dzieci w filozofii liberalnej? (s. 138-150). W: K. Michalski (Red.). Społeczeństwo liberalne. Kraków: Znak.

Krzemiński, I. (2015). Polska solidarna, Polska liberalna (s. 155-158). W: I. Krzemiński (Red.). Liberalizm polski. Warszawa: Wydawnictwo Akademickie SEDNO.

Legutko, R. (2011). Dlaczego nie lubię liberalizmu (s. 19-31). W: M. Wróblewski (Red.). Spór o liberalizm. Toruń: Wydawnictwo Uniwersytetu Mikołaja Kopernika.

Mises, L. von. (2009). Socialism. An economic and sociological analysis. Alabama: Anburn (reprint wydania z 1951).

Müller, J.-W. (2017). Co to jest populizm?. Warszawa: Wydawnictwo Krytyki Politycznej.

Novak, M. (2000). Catholic social thought and liberal institutions. Freedom and justice. New Brunswick-Oxford: Transaction Publishers.

Riker, W.H. (1982). Liberalism against populism. A confrontation between the theory of democracy and the theory of social choice. San Francisco: Freeman.

Setälä, M. (1999). Referendums and democratic government. Normative theory and the analysis of institutions. London-New York: McMillan Press.

Smith, R.C. (2014). Social conservatism, distractors, and authoritarianism: axiological versus instrumental rationality (s. 95-133). W: H.F. Dahms (Red.). Meditations of social life in the 21st century. Emerald Group Publ.

Sosnowski, J. (2015). Dzieje polskiego niby-liberalizmu (s. 53-62). W: M. Wróblewski (Red.). Spór o liberalizm. Toruń: Wydawnictwo Uniwersytetu Mikołaja Kopernika.

Szacki, J. (1994). Liberalizm po komunizmie. Warszawa-Kraków: Fundacja Batorego / Znak.

Szahaj, A. (2011). Antyliberalizm na skróty (s. 33-41). W: M. Wróblewski (Red.). Spór o liberalizm. Toruń: Wydawnictwo Uniwersytetu Mikołaja Kopernika.

Turowski, M. (2011). Liberalizm po komunitaryzmie? Filozoficzne koncepcje jednostki, wspólnoty i państwa jako źródła krytyki społecznej i politycznej. Toruń: Adam Marszałek.

Walicki, A. (2015). Nieporozumienia wokół liberalizmu (s. 200-209). W: I. Krzemiński (Red.). Liberalizm polski. Warszawa: Wydawnictwo Akademickie SEDNO. 
Wallerstein, E. (2004). Koniec świata jaki znamy. Warszawa: Scholar.

Wróbel, Sz. (2015). Liberalizm strachu i strach przed liberalizmem (s. 183-192). W: I. Krzemiński (Red.). Liberalizm polski. Warszawa: Wydawnictwo Akademickie SEDNO.

Wróblewski, M. (2011). Czy można wyjść poza spór o liberalizm? (s. 153-164). W: M. Wróblewski (Red.). Spór o liberalizm. Toruń: Wydawnictwo Uniwersytetu Mikołaja Kopernika.

Zakaria, F. (2018). Przyszłość wolności. Nieliberalna demokracja w Stanach Zjednoczonych i na świecie. Warszawa: Fundacja Kultura Liberalna. 